Komarnytskyi V. Delimitation of the Management Authorities in the Sphere of Nature Utilization and the Environment Protection

In the article the essence of management in the sphere of nature utilization and conservation, its importance for the organization of nature conservation activities and state and local governments, especially the interaction between these bodies and the problems arising in the course of this interaction, the way of their solution is analyzed.

Significant attention is paid to the analysis of the main conceptual provisions of administrative authority decentralization (delegation of authority from government authorities to local governments) identified in official documents and in the context of these research regulations provisions of environmental legislation that distribution of competencies between different levels of government, agencies that carry it. Attention is drawn to the role of natural resources division on state and local resources in ensuring the distribution of powers between the relevant authorities. According to this division natural resources of national importance managed by public authorities, local natural resources - local government bodies.

Tendency of gradually losing importance division as the main criterion of division of powers between these authorities is proved. In particular, the relevant question began referring natural resources considered under the state or municipal property (forest law) or for reasons of practical expediency of implementation of certain powers of the relevant authorities, and etc. In view of the author's opinion the division of natural resources of national and local importance in the legislation applied only in cases where it can have real meaning for the distribution of authorities between state and local governments.

Necessity of eliminating defects in the environmental legislation related to gaps in the authorities of local governments in problem solving of local nature conservation and declarative some of its provisions (particularly monitoring implementation of the legislation local governments control over compliance with laws on environmental protection) and etc.

Key words: managerial powers, decentralization of managerial authority in the field of nature management, environmental legislation, environmental protection. права та публічного адміністрування Маріупольського державного університету (м. Маріуполь, Україна)

Любчик О. А.

доктор юридичних наук, дочент, професор кафедри державно-правових дисциилін Луганського державного університету внутрішніх справ імені Е.О. Дідоренка

(м. Сєвєродонецьк, Україна)

\title{
ПРОБЛЕМИ ВИЗНАЧЕННЯ ТА ЗМІСТУ ПРАВА НА СУДОВИЙ ЗАХИСТ ТРУДОВИХ ПРАВ
}

У статті проаналізовано наукові погляди щодо сутності та змісту права на судовий захист трудових прав, його структурних елементів та порядку реалізації в сучасних умовах. Автори аргументовано пропонують наукові визначення цих

() Шелухін М. Л., Любчик О. А., 2019 
понять, а також понять «захист» та «охорона» трудових прав. Надано конкретні аргументовані пропозиції щодо вдосконалення законодавчого регулювання цих питань.

Ключові слова: право на судовий захист, захист трудових прав, захист та охорона, складові судового захисту, ефективність законодавства.

Постановка проблеми. ОДнією 3 теоретичних проблем трудового права є визначення, сутність і структура права на судовий захист трудових прав, а як наслідок - порядок його реалізації.

Беззаперечна важливість чіткого визначення цього наукового поняття, яке суттєво впливає не лише на доктринальну позицію щодо розвитку інститутів матеріального та процесуального права, але є досить важливим інструментом щодо формування ефективного законодавства, яке має грунтуватися на чіткій та узгодженій правовій термінології.

Для визначення права на судовий захист трудових прав передусім треба встановити зміст і межі поняття захисту трудових прав, а також розмежувати його 3 охороною трудових прав. Щодо цього висловлювалися багато науковців - правників, висновки яких можна поділити на три групи: 1) це тотожні поняття; 2) співвідносяться як ціле та частина; 3) не збігаються, майже не перемежовуються. Тож проблема досі $є$ не вирішеною, потребуючи дальшого вивчення. Вирішення цього наукового завдання має не тільки теоретичний сенс, але й практичне значення у напрямах виразного формулювання законодавчої позиції під час нормотворення, визначення мети й завдань діяльності державних органів та інших суб'єктів права, а також чітке структурування щодо цих параметрів системи органів держави та об'єднань громадян.

Аналіз останніх досліджень і публікацій. Проблему визначення поняття та змісту права на захист зокрема трудових прав вивчали такі фахівці в галузі права, як Г. П. Ареф'єв, І. В. Афанасьєв, В. С. Бабкова, С. Я. Вавженчук, Л. Д. Воєводін, С. В. Васильєв, В. П. Грибанов, Т. А. Занфірова, М. І. Іншин, А. М. Кучук, І. Є. Марочкін, Н. В. Урганова, П. М. Рабінович, 3. В. Ромовська, Б. Ю. Тихонова, Ф. А. Цесарський та інші.

Проте в Україні проблема визначення поняття, змісту та структури судового захисту трудових прав є дискусійною, потребуючи дальшого дослідження.

Формування цілей. Метою статті $є$ аналіз проблемних аспектів наукових поглядів щодо поняття, змісту та структури судового захисту трудових прав, формулювання власних визначень цих наукових понять та обгрунтування пропозицій щодо вдосконалення законодавчого використання таких термінів.

Виклад основного матеріалу. Охарактеризувати будь-яке правове явище не можна інакше, ніж з усвідомлення суті такого. Тому визначення права на судовий захист трудових прав слід розпочинати саме з визначення поняття судового захисту трудових прав.

Насамперед з' ясуємо співвідношення понять захист і охорона трудових прав, одностайності щодо трактування якого немає ані серед науковців, ані 
в текстах законодавства. Можна констатувати наявність принаймні трьох розбіжних точок зору щодо співвідношення понять захист і охорона.

Деякі науковці вживають ці терміни як синоніми, тобто не бачать різниці в їх змістовному наповнені. Частина з них подає визначення одного поняття через інше [1, с. 61] або заходи захисту визначає як правоохоронні засоби примусового впливу [2, с. 73]. Інші, як скажімо М. Вітрук, визначаючи охорону прав як діяльність, спрямовану на усунення перешкод для реалізації прав і обов' язків, на боротьбу з невиконанням обов'язків та зловживанням правами, на профілактику і попередження порушень прав і обов'язків, а захист - як діяльність, до якої вдаються в разі невиконання обов'язку або зловживання правом, а також, коли виникає перешкода для їх здійснення, або є суперечка про наявність самого права або обов'язку [3, с. 54], розмежовують визначення аналізованих понять, водночас вважаючи такі терміни синонімами й необхідності розмежовувати ці явища не вбачають, а точніше вважають, що терміни «захист» i «охорона» слугують для позначення одного правового явища, а тому їх відокремлення буде досить умовним [3, с. 54].

Ймовірно, основою цього напряму є лінгвістичне тлумачення слів «захист» та «охорона», коли поняття «захищати» подається як «охороняючи, захистити від замахів, від ворожих дій, від небезпеки» [4, с. 196], або ж «охорона» розуміється як «берегти, оберігати, захищати (виділення наше прим. авторів), тримати в цілісності, рятувати» [5, с. 774].

Водночас Л. Воєводін, дотримуючись позиції вживання термінів «захист» $\mathrm{i}$ «охорона прав» як синонімів, визнає, що підстави для розмежування цих понять з погляду юриспруденції існують. Насамперед захист прав здебільшого пов'язаний з діяльністю, яка здійснюється, коли суб'єктивні права громадян порушуються (переважно застосовуються заходи щодо відновлення порушених прав). Охорона ж означає діяльність щодо забезпечення нормальної реалізації суб'єктивних прав громадянами (переважно застосовуються попереджувальні заходи) [6, с. 41]. Більш категорично щодо цього висловлюється Н. Урганова, підтверджуючи, що ці терміни дуже близькі за значенням у філології, але акцентує увагу на відмінностях їх змісту в трудовому праві [7, с. 58].

Ці та інші факти взяті за основу другого напряму розуміння співвідношення понять «захист» $\mathrm{i}$ «охорона прав», а саме їх розмежування. Такого погляду дотримується, приміром, 3. Ромовська, коли порівнюючи поняття правової охорони і правового захисту, доходить висновку, що перше $є$ більш широким, оскільки «можливість захисту суб'єктивного права i конкретне його здійснення є однією зі складових правової охорони, а акт судового захисту одночасно спрямовується на охорону моральних засад суспільства, на відновлення порушеного права та усунення перешкод у його здійсненні через учинення відповідних дій» [8, с. 9-31].

А. Кучук вважає, що «охорона» - це родове поняття, яке охоплює захист [9, с. 10]. Така позиція щодо належності судових органів до певної системи (правоохоронних органів) є досить розповсюдженою. Наприклад, 
I. Бондаренко відносить до суб'єктів системи правоохоронних органів судові органи [10, с. 19].

У чинному Законі України «Про судоустрій і статус суддів» визначено: «Кожному гарантується захист його прав, свобод та інтересів у розумні строки незалежним, безстороннім і справедливим судом, утвореним законом» [11, ст. 7]. У ст. 55 Конституції України [12] теж ідеться про право на захист, зокрема судовий захист при порушенні прав людини. Навіть назва статті «Права і свободи людини і громадянина захищаються судом» підтверджує, що судові інстанції здійснюють тільки захисну функцію, що не відповідає наведеній науковій позиції. Охорона ж виступає не як право людини чи громадянина, а як обов'язок держави щодо збереження певних цінностей (честь, гідність, здоров'я, життя та інші цінності) [13, с. 48].

Основу третього напряму визначення понять «захист» $\mathrm{i}$ «охорона прав» складають твердження науковців щодо різниці змістовного наповнення цих понять, тобто змістовно вони зовсім не пересікаються, і як наслідок - не мають змішуватись у жодному разі. Учені стверджують, що ці поняття різняться не тільки змістовно та структурно, але й за формою [14, с. 70].

Ця позиція є дуже слушною, відповідаючи переважній більшості законодавчих формулювань щодо визначення сутності названих понять. Такі правові явища, як охорона прав i захист прав є різними, але взаємопов' язаними процесами та мають на меті забезпечення прав і свобод людини. Згідно 3 цим напрямом охорона - це i попереджувальна (профілактична) діяльність, а захист застосовується тільки в разі порушення певного суб'єктивного права або його невизнання чи оспорювання. Тобто охорона прав людини є механізмом безпосередньої дії охоронних норм права та організаційно-правової діяльності органів державної влади й місцевого самоврядування, установ і посадових осіб, а також громадських об'єднань 3 недопущення порушень прав та обов'язків людини, яку визначають як «сукупність різноманітних узаємозалежних між собою заходів, що здійснюються органами державної влади і громадських об'єднань, спрямованих на попередження порушень прав людини або усунення перешкод, що не є правопорушеннями, на шляху здійснення його прав і обов'язків» [15, с. 11]. Тобто охорона є безперервним процесом, який супроводжує реалізацію прав і здійснюється до такої у вигляді превентивних заходів та заходів щодо усунення перешкод, що не є правопорушеннями.

Отже, захист прав загально являє собою примусову правову (зокрема матеріально-правову і процесуальну) діяльність органів державної влади та управління, правоохоронних органів, громадських організацій і посадових осіб, а також громадян і осіб без громадянства стосовно зобов'язаної особи, здійснюваної законними засобами з метою підтвердження або відновлення оскарженого або порушеного права людини [16, с. 69].

Щодо цього звернемо увагу на необхідність розмежування і таких понять, як правовий захист і захист прав, що не є тотожними за змістом, оскільки позначають два різні правові явища, які до того ж співвідносяться як ціле (правовий захист) і частина (захист прав). 
Дотримання позиції стосовно розмежування понять охорони і захисту трудових прав констатуємо в нормах проекту Трудового кодексу України, коли поняття «охорона» вживається тільки в контексті заходів з охорони праці (прикладом, задля забезпечення охорони здоров'я), тоді, як чинне трудове законодавство під охороною трудових прав розуміє комплекс заходів та засобів, за допомогою яких встановлюються трудові права, визначається порядок їх реалізації, забезпечується їх дотримання. Отже, чинне трудове законодавство охорону трудових прав розуміє широко, залучаючи до нього й безпосередній захист трудових прав [13, с. 47], що не є виправданим.

Звернемо увагу й на те, що відповідно до ст. 2 Закону України «Про професійні спілки, їх права та гарантії діяльності» від 15.09.1999 № 1045-XIV [17] метою діяльності таких організацій визначено представництво і захист певних прав та інтересів при здійсненні ними фактично не тільки захисту, але й охорони. Така конструкція ст. 2 названого Закону багато в чому обумовлює трактування захисної функції профспілок як комплексної діяльності таких організацій на будь-якому організаційному рівні, спрямовану на попередження порушення трудових та соціальноекономічних прав трудящих, їх захист та відновлення [18, с. 7]. Автори погоджуються з таким твердженням з двох причин. По-перше, захист не має містити попередження порушення трудових та соціально-економічних прав трудящих (тобто охорону таких прав). Іншими словами, метою створення профспілок слід визначити представництво, охорону й захист трудових, соціально-економічних прав та інтересів, що має бути безпосередньо зазначено в цієї статті, а також у ст. 10 згаданого закону задля відповідності повноважень професійних спілок та їх завдань.

Тоді під сумнів ставляться й чотири організаційно-правові форми реалізації захисної функції профспілок, які виділив Ф. Цесарський: участь профспілок у відносинах соціального партнерства, включаючи відносини зі встановлення умов праці на підприємствах; у застосуванні встановлених умов праці на підприємстві; у вирішенні трудових спорів; у здійсненні профспілкового контролю за дотриманням законодавства про працю i правил охорони праці [19, с.7]. Беручи до уваги дотримання позиції розмежування понять захист і охорона трудових прав, зауважимо, що перша, друга і четверта форми реалізації захисної функції профспілок до таких навряд чи належать, оскільки мають бути віднесені до охоронної діяльності. Тоді реалізацією захисної функції слід визначити тільки участь профспілок у вирішенні трудових спорів. По-друге, захист і відновлення прав не слід ставити в один ряд, оскільки ці поняття співвідносяться як ціле і частина. Аналіз юридичної літератури з цивільного права дає змогу визначити право на захист одним з основних елементів будь-якого суб'єктивного права, що являє собою нормативно врегульовану можливість [20, с. 75] за своїм матеріальним змістом використання в межах, визначених законом, засобів самозахисту, можливість звернення до відповідного державного, самоврядного чи громадського органу або уповноваженої особи за захистом свого права чи інтересу [21, с. 183], можливість застосування безпосередньо 
самою уповноваженою особою юридичних заходів оперативного впливу на правопорушника. 3 боку процесуальної форми право на захист наділено принаймні трьома основними можливостями: по-перше, можливість уповноваженої особи звернутися з вимогою про захист порушеного або оспорюваного права чи охоронюваного законом інтересу до компетентного державного або громадського органу в позовній або іншій передбаченій законом формі; по-друге, можливість користуватися всіма передбаченими законом правами й гарантіями в процесі розгляду цієї вимоги, установленими стосовно до цієї форми захисту права; по-трете, можливість оскарження, опротестування у встановленому законом порядку рішення органу в цій справі [22, с. 104-106].

Право на судовий захист трудових прав слід визначати передусім як можливість певного суб'єкта трудових правовідносин звернутися до суду для відновлення порушеного, невизнаного або оспорюваного трудового права. Але постає запитання: чи наявність самої можливості звернення до суду і $є$ змістом поняття права на судовий захист? Звісно що ні, зміст цього права значно ширше, оскільки захист прав судом передбачає різні способи, а саме: відновлення, визнання, припинення порушення прав, припинення чи зміну правовідносин, відшкодування збитків та моральної шкоди, примусове виконання обов'язків, визнання угоди недійсною, визнання незаконними дій або бездіяльності, а також рішень [22, с. 10].

Тому розкриття змісту права на судовий захист без урахування можливостей процесуальної форми права на захист не є повним та обгрунтованим.

Вищенаведене дає змогу твердити, що право на судовий захист - це не тільки теоретична можливість звернутися до суду, але це право включає правомочності вимагати розгляд власної справи судом 3 винесенням рішення, а також вимагати примусового виконання. У такому разі процесуальна форма права на судовий захист має вміщувати чотири основні вимоги, а саме: 1) про захист порушеного або оспорюваного права чи охоронюваного законом інтересу (до відповідного компетентного органу) у позовній або іншій передбаченій законодавством формі; 2) щодо користування передбаченими законодавством правами, законними інтересами та їх гарантіями в процесі розгляду власної справи; 3) щодо оскарження, (опротестування) у встановленому законодавством порядку рішення органу [23, с. 105]; 4) щодо звернення за здійсненням примусового виконання рішення суду у випадках, передбачених законом.

3 огляду на це ми дещо не погоджуємося 3 Т. Занфіровою, яка, досліджуючи процесуальні правовідносини вирішення трудових спорів $\mathrm{i}$ конфліктів, зауважує, що ці правовідносини «визначають послідовність дій, спрямованих на досягнення конкретної цілі - захист і відновлення порушеного трудового права або реалізацію законного інтересу» $[18$, с. 86] у частині визначення цілі правовідносин як «захист й відновлення...». Безпосередне відновлення порушених, невизнаних чи оспорюваних прав, здійснюване судовими органами у встановленій процесуальній формі, є невід'ємною складовою процесу судового захисту прав. Отже, метою виникнення 
процесуальних правовідносин вирішення трудових спорів і конфліктів слід визначити захист порушеного, невизнаного або оспорюваного трудового права, відновлення якого є частиною процесу захисту, а тому виділення як частини цілі не передбачає. Аргументом на корись означеного є і позиція самої вченої щодо таких трьох стадій процесуальних трудових правовідносин, як звернення до відповідного органу, розгляд і вирішення спору або конфлікту між сторонами, виконання прийнятого рішення [18, с. 86- 87].

Зупинимося на визначенні права на судовий захист трудових прав як можливості звернення до суду суб'єкта трудових правовідносин, реалізація якої у встановленому законом порядку є підставою для справедливого й неупередженого розгляду порушеного питання судом у розумні строки 3 винесенням рішення, невиконання якого в добровільному порядку тягне можливість звернення за примусовим виконанням у межах виконавчого провадження.

Висновки. 3 огляду на вищевикладене доходимо висновку, що судовий захист трудових прав являє собою самостійне від охорони таких правове явище, які взаємопов'язані єдиною метою - забезпечення прав і свобод людини. До того ж охоронною слід визначити насамперед профілактичну й попереджувальну діяльність, що не пересікається із захистом, який застосовується в разі порушення певного права, його оспорювання чи невизнання. Тобто охорона є безперервним процесом, який триває упродовж реалізації суб'єктивних прав та має вигляд превентивних способів і заходів щодо усунення перешкод під час реалізації прав, які не є правопорушеннями. Якщо ж наявним є порушення певного права, то здійснюється його захист; конкретизація поняття останнього в разі здійснення судом виявляється у визначенні такого як застосування способів захисту судом у разі порушення, оспорювання, невизнання трудових прав суб'єктів трудових правовідносин.

Акцентовано увагу на тому, що захист трудових прав не обмежується винесенням певного рішення суду, оскільки лише виконання останнього свідчить про досягнення стану захищеності суб'єктів трудових правовідносин. Це означає, що право на судовий захист охоплює не тільки три загальні можливості з боку процесуальної форми права на захист (звернутися за захистом, користуватися всіма передбаченими законом правами й гарантіями в процесі розгляду вимоги, можливість оскарження, опротестування у встановленому законом порядку рішення органу в цій справі), але й четверту - можливість звернутися за здійсненням примусового виконання рішення суду в разі відсутності виконання такого в добровільному порядку.

\section{Використані джерела:}

1. Воеводин Л. Д. Система конституционных прав и свобод советских граждан, юридические условия и средства их обеспечения и охраны // Юридические гарантии конституционных прав и свобод в социалистическом обществе. Москва: Изд-во Московского ун-та. 1987. С. 59-75.

2. Харитонова О. І., Харитонов Є. О. Порівняльне право Свропи: Основи порівняльного правознавства. Європейські традиції. Харків: Одиссей, 2002. 592 с. 
3. Витрук Н. В. Правовой статус личности в СССР. Москва : Юрид лит., 1985. 175 c.

4. Ожегов С. И. Словарь русского языка / под ред. докт. филол. наук, проф. Н. Ю. Шведовой.: Рус. яз., 1984. 797 с.

5. Даль В. И. Толковый словарь живого великорусского языка. Т.2. Москва: «Русский язык», 1979. 780 с.

6. Воеводин Л. Д. Юридические гарантии конституционных прав и свобод личности в социалистическом обществе. Москва: Изд-во Московского унта, 1987. 343 с.

7. Урганова Н. В. Охоронна функція трудового права. Збірник наукових праць Харківського національного педагогічного університету імені Г. С. Сковороди «Право». 2007. № 9. С. 57-59.

8. Ромовская 3. В. Защита в советском семейном праве. Львов: Изд-во при ЛГУ издательского объединения «Вища школа», 1985. 179 с.

9. Кучук А. М. Правоохоронні органи в Україні: нормативне регулювання та критерії виокремлення. Науковии вісник Дніпропетровського державного університету внутрішніх справ. 2008. № 2 (38). С. 10-17.

10. Бондаренко І. В. Правоохоронна діяльність і правоохоронні органи (поняття та ознаки). Право Украӥни. 2003. № 4. С. 18-21.

11. Закон України «Про судоустрій і статус суддів» від 02.06.2016 № 1402-VIII. Відомості Верховної Ради України. 2016. №31. Ст. 545. URL: https://zakon.rada.gov.ua /laws/show/1402-19 (дата звернення 21.02.2019).

12. Конституція України від 28 червня 1996 р. Відомості Верховної Ради України. 1996. № 30. Ст. 141.

13. Вавженчук С. Я. Співвідношення понять «захист» та «охорона» трудових прав в чинному законодавстві. Форум права. 2010. № 1. C. 45-49. URL: http:/ / www.nbuv.gov.ua/ e-journals/FP/2010-1 (дата звернення 25.01.2019).

14. Арефьев Г. П. Некоторые вопросы понятия охраны субъективных прав // Проблемы защиты субъективных прав и советсткое гражданское судопроизводство. Ярославль : Ярославльский государственный университет, 1981. С. 68-75.

15. Тихонова Б. Ю. Субъективные права советских граждан, их охрана и защита: автореф. дисс. ... канд. юрид. наук. Москва, 1972. 22 с.

16. Іншин М. І. Значення захисту трудових прав працівників у становленні правової держави. Вісник Національної академії правових наук України. 2014. № 2 (77). C. 66-71. URL: http:/ /visnyk.kh.ua/web/uploads (дата звернення 25.01.2019).

17. Закон України «Про професійні спілки, їх права та гарантії діяльності» від 15.09.1999 № 1045-XIV. Відомості Верховної Ради України. 1999. № 45. С. 397. URL: https:/ / zakon.rada.gov.ua/laws/show/1045-14 (дата звернення 25.01.2019).

18. Занфірова Т. А. Процесуальні правовідносини 3 вирішення трудових спорів і конфліктів. Економіка та держава. 2007. № 4. С. 86-88.

19. Цесарський Ф. А. Захисна функція профспілок, форми їі реалізації. Автореф. дис. ... канд. юрид. наук: 12.00.05. Національна юридична академія ім. Ярослава Мудрого. Харків, 2004. 20 с.

20. Цивільне право України: Академічний курс: підруч.: у двох томах / за заг. ред. Я. М. Шевченко. Т.1. Загальна частина. Київ: Конщерн «Видавничий Дім «Ін Юре», 2003. 520c.

21. Цивільне право України: підручник / Є. О. Харитонов, Н. О. Саніахметова. Київ : Істина, 2003. 776 с. 
22. Грибанов В. П. Осуществление и защита гражданских прав. Изд. 2-е, стереотип. Москва: «Статут», 2001. 411 с. (Классика российской цивилистики).

23. Васильев С. В. Гражданский процесс: учебное пособие. Издание второе, дополненное. Харьков : ООО «Одиссей», 2007. 512 с.

Стаття надіӥшла до редколегії 10.01.2019

Шелухин М. Л., доктор юридических наук, профессор, профессор кафедры права и публичного администрирования Мариупольского государственного университета (г. Мариуполь, Украина)

Любчик А. А., доктор юридических наук, доцент, профессор кафедры государственно-правовых дисциплин Луганского государственного университета внутренних дел имени Э. А. Дидоренка (г. Северодонецк, Украина)

Проблемы определения и содержания права на судебную защиту трудовых прав

В статье проанализированы научные взгляды относительно сущности и содержания права на судебную защиту трудовых прав, его структурных элементов и порядка реализации в современных условиях. Авторы предлагают научные определения этих понятий, а также понятий «защита» и «охрана» трудовых прав. Предложены конкретные аргументированные предложения по совершенствованию законодательного регулирования этих вопросов.

Ключевые слова: право на судебную защиту, защиту трудовых прав, защита и охрана, составляющие судебной защиты, эффективность законодательства.

\section{Shelukhin M., Liubchyk O. Problems of Determination and Content of the Right to Judicial Protection of Labor Rights}

The article analyzes the scientific views on the essence and content of the right to judicial protection of labor rights, its structural elements and the procedure for its implementation in modern conditions. The authors argue for scientific definitions of these concepts, as well as the concepts of "protection" and "protection" of labor rights. Specific and substantiated proposals for improving the legislative regulation on these issues are proposed.

One of the theoretical problems of labor law is the problem of determining the nature, essence and structure of the right to judicial protection of labor rights, and as a consequence of the procedure for its implementation.

The emphasis is placed on the importance of a clear definition of this scientific concept, which substantially affects not only the doctrinal position regarding the development of institutions of material and procedural law, but is a very important tool for the formation of effective legislation, which should be based on a clear and consistent legal terminology.

It is proved that in order to determine the right to judicial protection of labor rights, it is first of all necessary to determine the meaning and scope of the concept of the protection of labor rights, as well as to distinguish this concept from the protection of labor rights. On this occasion, many scholars - lawyers, the conclusions of which can be divided into three directions 1) these are identical concepts, 2) relate as an integer and part, 3) do not coincide, almost interspersed.

So the problem is still not solved and needs further study. The decision of this scientific problem has not only theoretical sense, but it is of practical importance in the 
areas of clear formulation of the legislative position during the normative setting, the definition of the purpose and tasks of the activity of state bodies and other subjects of law, and the clear structuring of these parameters of the system of state bodies and associations of citizens.

Key words: the right to judicial protection, protection of labor rights, protection and protection, the components of judicial protection, the effectiveness of legislation. 